\title{
A bizarre tandem-horned elasmothere rhino from the Late Miocene of northwestern China and origin of the true elasmothere
}

\author{
DENG Tao ${ }^{1,2^{*}}$, WANG ShiQi ${ }^{1} \&$ HOU SuKuan ${ }^{1}$ \\ ${ }^{1}$ Key Laboratory of Evolutionary Systematics of Vertebrates, Institute of Vertebrate Paleontology and Paleoanthropology, Chinese Academy of \\ Sciences, Beijing 100044, China; \\ ${ }^{2}$ Department of Geology, Northwest University, Xi'an 710069, China
}

Received September 18, 2012; accepted October 19, 2012; published online November 27, 2012

\begin{abstract}
Although the modern Indian and Javan rhinos have a single horn on their noses, the extinct one-horned rhino Elasmotherium was a source for the legendary unicorn, because the latter had a very long horn on its forehead and lived with the prehistoric human beings who drew its images on cave paintings. Elasmothere rhinos first appeared in South Asia in the Early Miocene, but the origin of Elasmotherium has been unclear. All other elasmotheres have a weak or strong nasal horn, whereas Elasmotherium seems to lose the nasal horn of its ancestors and to get a huge frontal horn apparently abruptly. Here we report the first discovered skull of Sinotherium lagrelii from the Late Miocene red clays in the Linxia Basin, northwestern China. This skull has an enormous nasofrontal horn boss shifted posteriorly and a smaller frontal horn boss, which are connected to each other, indicating an intermediate stage for the single frontal horn of Elasmotherium. Morphological and phylogenetic analyses confirm that Sinotherium is a transitional taxon between Elasmotherium and other elasmotheres, positioned near the root of the giant unicorn clade and originated in a subarid steppe. The posteriorly shifted nasal horn has a more substantial support and the arched structure of the nasofrontal area is an adaptation for a huge horn.
\end{abstract}

Rhinocerotidae, elasmothere, Sinotherium, Late Miocene, Linxia Basin

Citation: Deng T, Wang S Q, Hou S K. A bizarre tandem-horned elasmothere rhino from the Late Miocene of northwestern China and origin of the true elasmothere. Chin Sci Bull, 2013, 58: 1811-1817, doi: 10.1007/s11434-012-5574-4

The origin and morphology of mammalian horns have an important significance for anatomy, ecology and evolution [1], but horns of many extinct forms are rarely known, including elasmotheres. The extinct one-horned rhino Elasmotherium had a two-meter-long horn on its forehead and lived with the prehistoric human beings who drew its images on cave paintings [2,3]. Elasmothere rhinos first appeared in South Asia in the Early Miocene [4], but the origin of Elasmotherium has been unclear. All other elasmotheres have a weak or strong nasal horn, whereas Elasmotherium seems to lose the nasal horn of its ancestors and to get a huge frontal horn abruptly [5].

Transition of a nasal horn to a frontal horn in elasmotheres has been difficult to explain, because a major trans-

*Corresponding author (email: dengtao@ivpp.ac.cn) formational gap exists between nasal-horned ancestors and frontal-horned descendants. A partially preserved skull (IVPP V 18539, housed at the Institute of Vertebrate Paleontology and Paleoanthropology, Chinese Academy of Sciences, Beijing) found from the red clays of the Late Miocene Liushu Formation in the Linxia Basin, northwestern China is referred to the huge rhinoceros, Sinotherium lagrelii based on its short and high maxillary face, and provides new evidence on the origin of the giant unicorn Elasmotherium.

Previously, S. lagrelii was represented by some cranial and mandibular fragments and isolated teeth from the Late Miocene deposits in Baode County, Shanxi Province, China [6] as well as Kazakhstan [7-10] and Mongolia [11], so its horn situation was unknown. S. lagrelii is the closest to the Pleistocene Elasmotherium in dental morphology, but the nature of its frontal horn has not been determined [3]. This 
skull (V 18539) proves that $S$. lagrelii has a posteriorly shifted nasofrontal horn, derived from the condition seen in early elasmotheres, and a smaller frontal horn, so it is different from Ningxiatherium with a single nasal horn [12,13] and Elasmotherium with a single frontal horn [3], but it is a morphological intermediate in the nasal-to-frontal horn transition of elasmotheres and builds a connection for the evolution and biogeography of the derived elasmotheres.

\section{Geological setting}

The Linxia Basin is located in Gansu Province, northwestern China and at the triple-junction of the northeastern Tibetan Plateau, western Qinling Mountains and the Loess Plateau, delineated by high angle deep thrusts. The lateral extent of the Linxia Basin is marked by tectonic boundaries on the northern, western, and southern edges, but its eastern margin is poorly determined. The basin is filled with 700-2000 m of late Cenozoic deposits, mainly red in color and dominated by lacustrine siltstones and mudstones punctuated by fluvial conglomerates or sandstones, and 30-200 m of the Quaternary loess sediments [14]. The Cenozoic deposits of the Linxia Basin begin with the Late Eocene deposits, which lap over the Cretaceous deposits in the Maxian Mountain to the north. Throughout the central part of the Linxia Basin, the oldest deposits were laid down unconformably on the granite of presumed Paleozoic age. To the southwest of the Linxia Basin, the Tibetan Plateau consists of the DevonianPermian terrestrial and marine deposits and the Triassic submarine fan deposits, which were shed by the eastsoutheast striking Qinling Mountain belt to the east of the plateau [15].

The lithological sequence of the Linxia Basin was revised and the following units were adopted: the Oligocene Tala and Jiaozigou formations, the Miocene Shangzhuang, Dongxiang, Hujialiang, and Liushu formations, the Pliocene Hewangjia and Jishi formations, and the Early Pleistocene Wucheng Formation [16,17]. Among them, the Liushu Formation consists of light yellowish brown carbonate-cemented siltstones intercalated with a few thin beds of mudstones and marls, developing substantial mottles and big carbonate nodules and bearing the abundant fossils of the Hipparion fauna, which are also called "the Hipparion red clays" [18]. Toward the southern Linxia Basin, more conglomerates are intercalated in the Liushu Formation.

The Liushu Formation is up to $100 \mathrm{~m}$ thick and widely distributed within the Linxia Basin, with a paleomagnetic age between 11 and $6.4 \mathrm{Ma}[15,19,20]$. The elasmothere skull (V 18539) was collected from the upper part of the Liushu Formation at Huaigou (IVPP locality: LX 0029, $35^{\circ} 22^{\prime} 51.4^{\prime \prime} \mathrm{N}, 103^{\circ} 26^{\prime} 54.4^{\prime \prime} \mathrm{E}$ ) in Guanghe County, Gansu Province, with an age of about $7 \mathrm{Ma}$, based on paleomagnetic study [19]. Sinotherium lagrelii is the most derived and latest elasmothere found in the Linxia Basin, accompa- nying one bear (Ursavus sp.), one badger-like mustelid (Parataxidea sinensis), three hyenas (Hyaenictitherium wongii, $H$. hyaenoides, and Ictitherium sp.), three felids (Machairodus palanderi, Metailurus major, and Felis sp.), one chalicothere (Ancylotherium sp.), one three-toed horse (Hipparion coelophyes), one deer (Dicrocerus sp.), one giraffe (Palaeotragus microdon), and two bovids (Sinotragus wimani and Protoryx sp.). Of these, the combination of $H$. coelophyes, S. wimani, and Protoryx sp. strongly support a late Late Miocene age [21]. A pollen analysis of the Liushu Formation showed that grasses increased significantly and became dominant, especially xerophilous and sub-xerophilous grasses, along with some broadleaves of temperate and warm temperate zones, suggesting that the vegetation of the Liushu Formation belonged to a subarid or arid steppe [22].

\section{Description}

The skull (V 18539) of Sinotherium lagrelii lacks the anterior portion and all teeth, and is missing the free part of the nasals and the dorsal part of the occipital (Figures 1,2). The lateral walls of the remaining nasal bones descend strongly and are nearly vertical. The posterior part of the nasals at the entire width is strongly swollen and highly elevated to form a large area of rough surface that extends to the upper part of the lateral wall of the nasals. The rough surface has a broad and flat roof that is slightly inclined forwards, on the middle and posterior part of which is a more rugose pentagonal depression of $187 \mathrm{~mm}$ long and $128 \mathrm{~mm}$ wide, with a posterior opening. The nasal base is slightly constricted, and the anterior rim of orbit projects strongly, so an anteriorly oriented broad surface forms in front of the orbit (Figure 1(b)). Because the maxillary bone is crushed, the precise description for the situation of the orbits is not available. The cross section of the nasal bones is arched with a sagittal crest. The nasals are completely fused to each other. The nasal central groove is absent, but a shallow and wide depression is well-developed (Figure 1(a)).

The maxillary surface before the orbit is high, vertical, smooth and flat, which is identical with the unique feature on this area of Sinotherium lagrelii from Baode, Shanxi [6]. The whole upper rim of the orbit is thick, straight, rough and projected, with a notch between the supraorbital tuberosity and the lacrimal tubercle. Because the nasals are highly raised, the orbit is located in the middle position of the lateral side of the skull. On the other hand, the dorsal profile of the skull is strongly concave, so the upper rim of the orbit is not far from the dorsal surface of the frontal bone. The lacrimal tubercle is large, thick, and triangular in shape. The postorbital process is absent on the frontal bone. The posterior part of the zygomatic arch is low. The occiput is so highly elevated that the parietal bones form a very steep surface (Figure 1(b)). The maximum width of the dorsal surface of the skull is at the supraorbital tuberosity. 

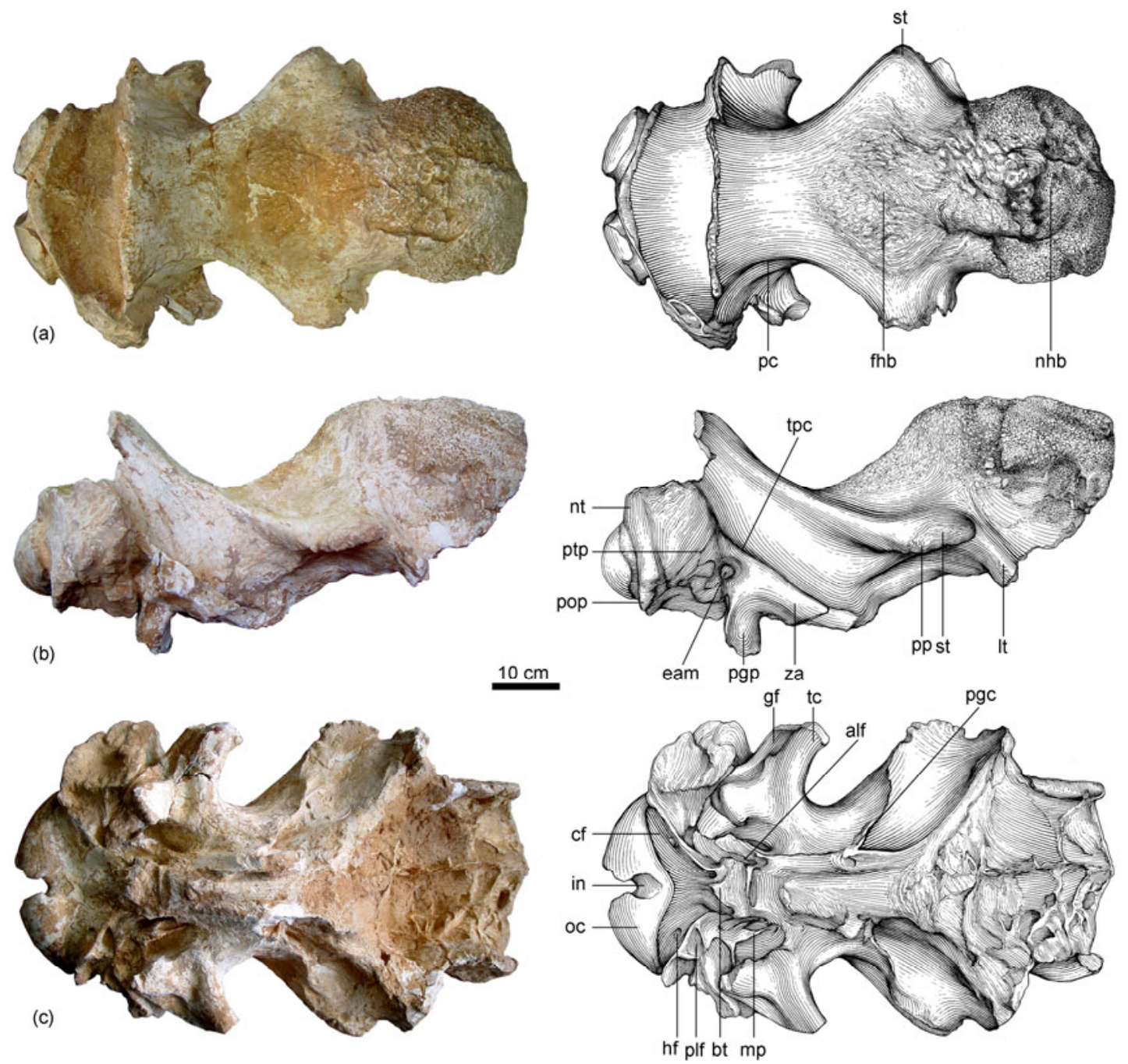

Figure 1 Skull (V 18539) of Sinotherium lagrelii from the Linxia Basin. (a) Dorsal view; (b) lateral view; (c) ventral view. alf, anterior lacerate foramen; bt, basal tuberosity; cf, condyloid fossa; eam, external auditory meatus; fhb, frontal horn boss; gf, glenoid fossa; hf, hypoglossal foramen; in, intercondyloid notch; plf, posterior lacerate foramen; lt, lacrimal tubercle; mp, muscular process; nhb, nasofrontal horn boss; nt, nuchal tuberosity; oc, occipital condyle; pc, parietal crest; pgc, pterygoid canal; pgp, postglenoid process; pop, paroccipital process; pp, postorbital process; ptp, posttympanic process; st, supraorbital tuberosity; tc, temporal condyle; tpc, temporal crest; za, zygomatic arch.

The diameter of the frontal horn boss is $161 \mathrm{~mm}$ wide and $121 \mathrm{~mm}$ long. The braincase is wide and high, with nearly vertical side walls. The parietal crests are broadly separated, with a minimal width of $161.5 \mathrm{~mm}$, and the surface between the parietal crests is wide, flat, and smooth. Anteriorly the parietal crest is strong, thick and projected laterally, and then it weakens posteriorly (Figure 1(a)).

The suture between the sphenoid and the orbit has been fused. The intercondyloid notch is narrow and deep, with a minimum width of $17.5 \mathrm{~mm}$ in ventral aspect and a spacious cylinder-like interior. The occipital condyles are anteroposteriorly short, with a length of about $68 \mathrm{~mm}$, and very wide transversely, with a distance of $239 \mathrm{~mm}$ between their lateral margins (Table 1). The pterygoid process of the sphenoid is thick and high, and the pterygoid canal is large. The temporal condyle is anteroposteriorly wide, convex, flat, and anteriorly curved, with a posteriorly curved inner part that extends to the anterior border of the median side of the postglenoid process. The articular fossa behind the temporal condyle is transversely wide and smooth. The postglenoid processes is robust and lightly twisted, with a narrow, triangular cross section and an interiorly oblique anterior margin. The posttympanic process is well developed and laterally expanded, and it is not fused with the postglenoid process, but there is an ossified external auditory meatus between them. The posttympanic, mastoid and paroccipital processes are fused to each other at their bases. There is a distance of $97 \mathrm{~mm}$ between the anterior margin of the posttympanic process and the posterior margin of the paroccipital process. Both paroccipital processes are lost, but their remains still indicate a large transverse width (Figure 1(c)).

The hypoglossal foramen is large and compressed, and it is situated in the lateral side of the middle of the condyloid 

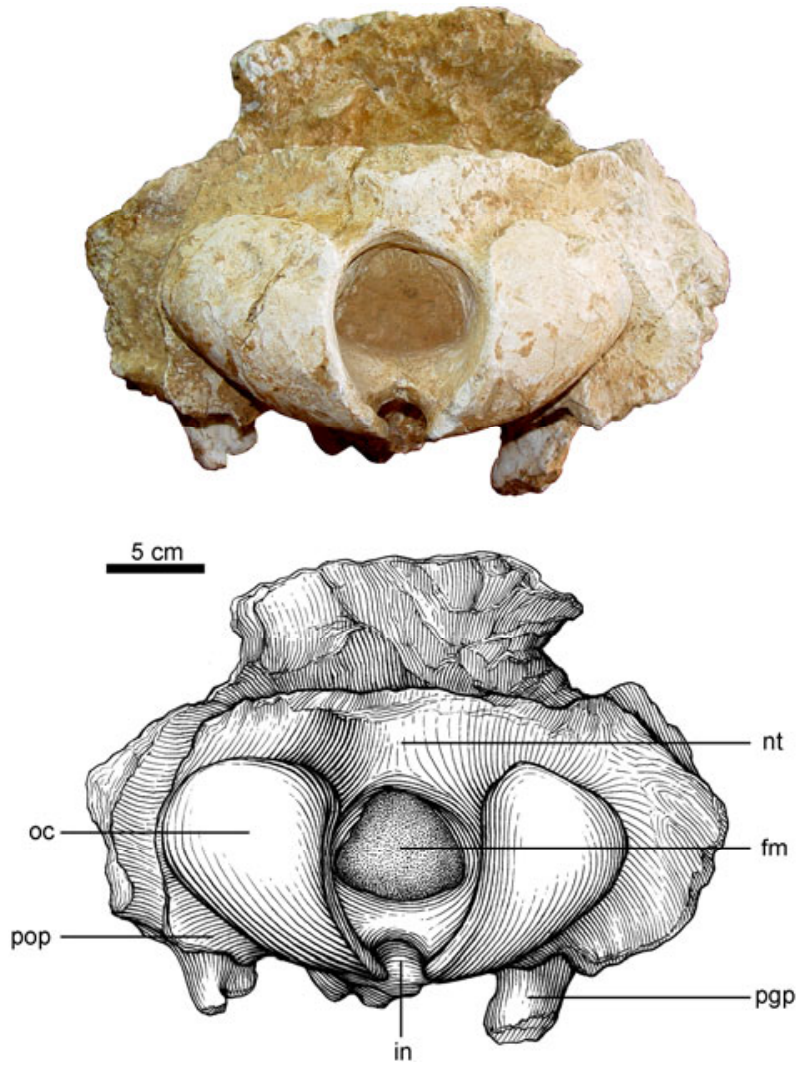

Figure 2 Occipital view of the skull (V 18539) of Sinotherium lagrelii from the Linxia Basin. fm, foramen magnum; in, intercondyloid notch; nt, nuchal tuberosity; oc, occipital condyle; pgp, postglenoid process; pop, paroccipital process.

fossa that is broad and shallow. The basal tuberosity is situated in the front of the lacerate foramen, and it is broad and rough, with a strongly laterally expanded anterior half, but without a distinct sagittal ridge. The basioccipital bone is low and flat so that it is almost undistinguished from the lateral condyloid fossae. The occipital and ventral surface of the condyles is rounded, without a median ridge. There is a small tubercle on the posterior part of the sagittal axis of the sphenoid. The basioccipital bone has an angle of $143^{\circ}$ with the basisphenoid bone. The ventral surface of the sphenoid body is rounded and convex. The hyoid process of the petrous bone is large and circular, with a diameter of $21 \mathrm{~mm}$. The posterior half of the muscular process is very wide and high, with a width of $16 \mathrm{~mm}$, the anterior half is slender, and the tip is situated at the level of the midline of the glenoid fossa. The tympanic bulla is small and low. The ethmoidal, optic and orbital foramina are deeply hidden (Figure 1(c)).

The upper part of the occipital surface is broken. The nuchal tuberosity is a strong inverse triangle. The lateral part of the occipital surface is very rough and inclined anterolaterally. The lateral margin of the occipital crest is strongly inclined anteriorly and slightly divergent inferiorly, and it extends anteriorly to form the straight temporal crest. The foramen magnum is very large, elliptical, and higher than wide. The upper margin of this foramen is lower than the upper margin of the occipital condyles. The occipital condyles are very large, indicating the connection with the neck is very powerful in order to support the weight of a dolichocephalic head with two huge horns (Figure 2).

\section{Comparison}

The nasofrontal area of the skull is strongly elevated and rough to form a huge and hollow dome (Figure 1), in sharp contrast to the flat and smooth area in large nasal-horned elasmotheres, such as Iranotherium [24], Parelasmotherium [25] and Ningxiatherium [12,13]. This reduces the weight of the nasal and frontal bones. The nasal horn boss is shifted posteriorly to reach the frontal bone and to connect to the frontal horn boss, and such a horn combination has not appeared in any other extinct or extant rhinoceros. The dorsal surface of the horn bosses has many massive swellings in order to strengthen the adhesion of a huge nasal horn and a smaller frontal horn (Figure 1(a)), and the ventral surface has an ossified sagittal septum with a thickness of $6.5 \mathrm{~mm}$ and many oblique lateral ribs to form a trussed structure (Figure 1(c)) in order to enhance support like the leaf structure of the giant waterlily (Victoria) [26]. An enlarged nasal horn without other compensation would make the nasals

Table 1 Cranial measurements and comparison of Sinotherium lagrelii $(\mathrm{mm})^{\mathrm{a}}$

\begin{tabular}{|c|c|c|c|c|}
\hline Measurements & $\begin{array}{c}\text { S. lagrelii } \\
\text { V } 18539\end{array}$ & $\begin{array}{l}\text { E. sibiricum } \\
\text { NHM } 12429\end{array}$ & $\begin{array}{c}P . \text { linxiaense } \\
\text { HMV } 1411\end{array}$ & $\begin{array}{c}\text { N. euryrhinus } \\
\text { HMV } 1449\end{array}$ \\
\hline 5 Minimal width of the braincase & 186 & $\sim 194$ & 166 & 190 \\
\hline 16 width between mastoid processes & 410 & 432 & 306 & 379 \\
\hline 17 Minimal width between the parietal crests & 161.5 & 181 & 113.6 & 121 \\
\hline 18 Width between postorbital processes & 390 & 408 & 228 & 270 \\
\hline 19 Width between supraorbital tubercles & 405 & 381 & 231.5 & 282 \\
\hline 20 Width between lacrimal tubercles & 375 & 409 & $\sim 207$ & 400 \\
\hline 22 Width of the nasal base & 238 & 137 & 158.4 & 235 \\
\hline 31 Width of foramen magnum & 78 & & 88 & 71 \\
\hline 32 Width between occipital condyles & 239 & 203 & 186 & 215 \\
\hline
\end{tabular}

a) Measurement numbers are as defined by Guérin [23]. NHM: Natural History Museum in London, UK; HMV: Specimen prefix of the Hezheng Paleozoological Museum in Gansu, China. 
impossible to support, even with an ossified nasal septum, so the nasal horn has to shift posteriorly toward the frontal bone.

The skull exhibits enormous occipital condyles with a distance of $239 \mathrm{~mm}$ between their lateral margins (Figure 2), as in other large nasal-horned elasmotheres [12,13,24] and giant rhinos [27], indicating their dolichocephalic and heavy skulls [28]. This feature is also shown in Iranotherium: the condyles in the male are much larger than in the female, because the male has a larger horn [24]. The longer skull yields great torque on the neck of elasmotheres. On the premise of retaining a huge horn, the elasmothere strategy followed two solutions: first, the nasal horn shifts posteriorly to become the frontal horn; second, the dolichocephalic skull becomes the brachycephalic [3]. Both changes occurred in the skull of Elasmotherium, so its occipital condyles became smaller compared with the larger ones of Sinotherium, and its second premolars were lost [3], although Sinotherium retained them [6]. Based on the skull, the nasal horn is known to enlarge gradually and shift posteriorly

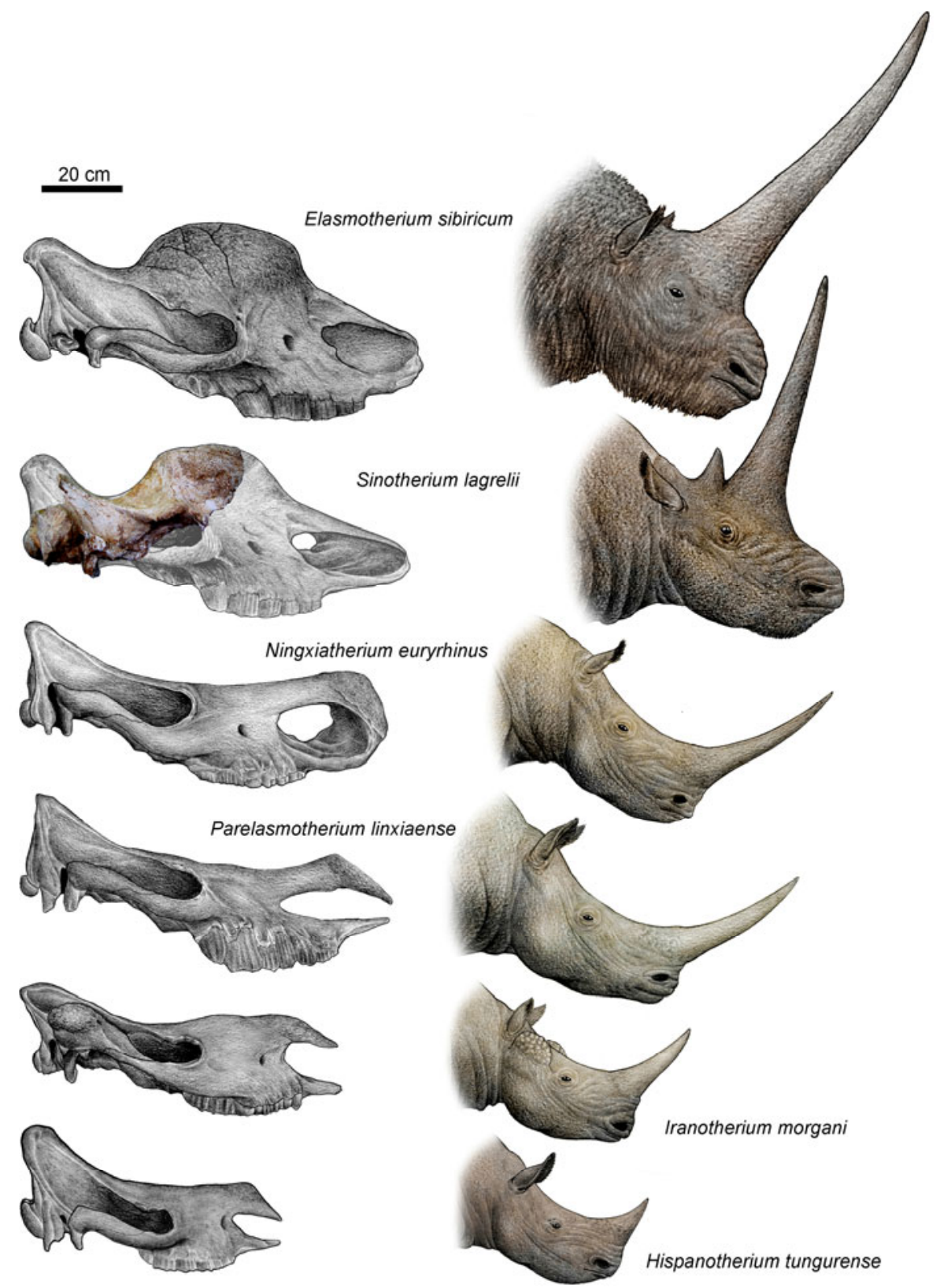

Figure 3 A series of six elasmotheres species from the Middle Miocene to the Late Pleistocene. They display an increase in skull size and development from a nasal horn to a frontal horn. These skulls are reconstructed based on AMNH 26531 (Tunggur in Inner Mongolia, Middle Miocene) for Hispanotherium tungurense, HMV 0979 (Houshan in Guanghe, Gansu, Late Miocene) for Iranotherium morgani, HMV 1411 (Guonigou in Dongxiang, Gansu, Late Miocene) for Parelasmotherium linxiaense, HMV 1449 (Guonigou in Dongxiang, Gansu, Late Miocene) for Ningxiatherium euryrhinus, V 18539 (Huaigou in Guanghe, Gansu, Late Miocene) for Sinotherium lagrelii, and NHM 12429 (Sarepta in Russia, Late Pleistocene) for Elasmotherium sibiricum. 
toward the frontal bone in derived elasmotheres; meanwhile, a smaller frontal horn develops and finally fuses with the nasal horn to form a huge frontal horn (Figure 3). This discovery explains a distinct transverse suture on the middle of the frontal horn boss of Elasmotherium (Kurten, 1968), which was not understood in the past but is now determined as a remnant of the nasal and frontal horn bosses fusing to each other.

The parietal crests of $S$. lagrelii are widely separated (Figure 1(a)), as on other Miocene rhinocerotines, such as Dicerorhinus ringstroemi [6] and Diceros gansuensis [29]. The skull roof is very concave like that of Elasmotherium, and the occiput is relatively high and over-hanging the occipital condyles, indicating a posteriorly inclined occipital surface (Figure 1(b)). The situation of the occipital surface resembles those in other elasmotheres [3,12,13,24] or woolly rhinos [30,31], and is more inclined than in modern Asian and black rhinos [23]. Rhinoceroses with an occiput strongly inclined postero-dorsally and a nuchal crest extending beyond the condyles are thought to graze, i.e. to feed on grasses [32]. The posttympanic process is huge and separated from the postglenoid process but fused with the paroccipital process. The external auditory pseudo-meatus is partially closed (Figure 1b), which differs from the open situation in other elasmotheres. Although both zygomatic arches are broken, the remaining ends indicate their position is very low. The orbits of S. lagrelii are partially preserved, and their upper rims are relatively projected, which are different from those of the nasal-horned elasmotheres, but similar to those of the frontal-horned elasmotheres [3]. The projected degree falls in the ranges of the frontal-horned elasmotheres and the modern African rhinos [23].

\section{Discussion}

In the previous phylogenetic analyses, the position of $S$. lagrelii was not completely determined due to the lack of its skull $[3,13,33,34]$. Given the new discovery, the cranial characters of $S$. lagrelii suggest that the monophyletic group including Sinotherium lagrelii, Elasmotherium sibiricum, and $E$. caucasium would be appropriate, where $S$. lagrelii is the most basal and connects elasmotheres having a nasal horn but no a frontal horn with elasmotheres having a frontal horn but no nasal horn (Figure 3). This is consistent with the clade originating by the Late Miocene in China, and Elasmotherium being separate from Sinotherium at least since the Pliocene. The clade of Elasmotherium, Sinotherium, Parelasmotherium and Ningxiatherium shares a number of characters including a huge horn boss, posteriorly shifted and projected orbits above or behind M3, widely separated parietal crests, huge posttympanic processes fused with paroccipital processes, a circular foramen magnum, a posteriorly inclined occipital side, enormous occipital condyles, and extremely high-crowned teeth. The lack of postcranial evidence for most elasmotheres restricts comparisons of most other skeletal regions.

The area of distribution for Sinotherium in East Asia is similar to that of the steppe Hipparion fauna in the Late Miocene. According to the evidence from lithology, carbon isotopes, paleobotany, taxonomic framework, mammalian diversity and faunal similarity, the paleoenvironment of the Hipparion fauna in China was a subarid open steppe [35]. The low positioned head, dolichocephalic skull, massive cement filling, well-developed secondary folds, and wrinkled enamel provide a means for the cheek teeth of Sinotherium to resist the abrasion of high-fiber diets so that it could graze on tough grasses. Sinotherium is a huge-sized rhinoceros with a weight up to 7 tonnes, much heavier than the largest modern African white rhino (3.2 to 3.6 tonnes [36]), so if it lived by the river, it was easy to get stuck in the wet mud. More likely, S. lagrelii lived in an open, usually dry environment (Figure 4) where droughts frequently occurred in northern China [37]. Early East Asian large

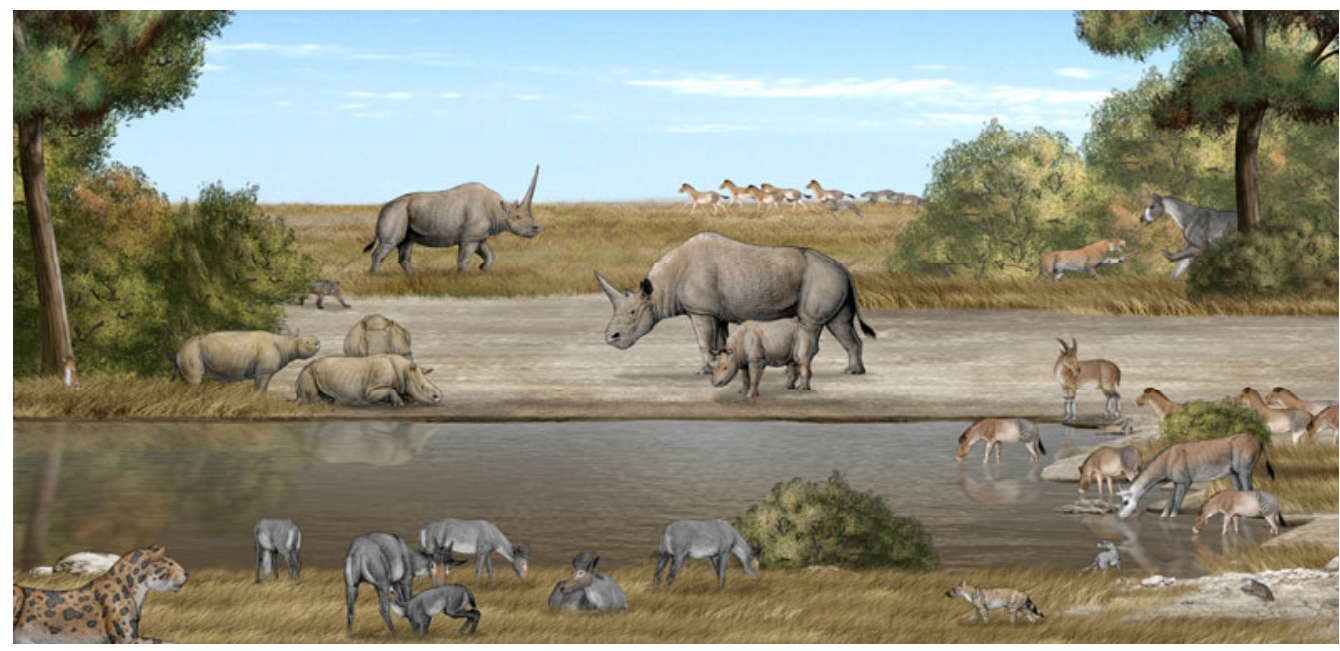

Figure 4 Habitat reconstruction of Sinotherium lagrelii in the Linxia Basin during the Late Miocene. 
elasmothere populations may have frequented steppe environments more than their more wet-adapted descendants in southern Russia [5]. The ongoing cooling and the development of the Arctic ice-sheet would have caused significant strengthening of Asian continental aridity, with moisture prevented from reaching the Asian interior due to the uplifted Himalayan topography that blocked flow from the south $[38,39]$. Because $S$. lagrelii is phylogenetically near the root of the frontal-horned elasmothere radiation, the reconstruction of steppe habitat for the species is an alternative against the proposal that the frontal-horned elasmotheres lived in wet habitat by rivers [5].

We are grateful to Prof. Qiu Zhanxiang, Prof. Wang Banyue, Prof. Xie Guangpu, Shi Qinqin, and Chen Shaokun for their support in the fieldwork. We thank Mr. Shen Wenlong and Mr. Chen Yu for their illustrations, and Dr. Lawrence Flynn for his English improvement. We are also grateful to the reviewers of this manuscript for their constructive comments. This work was supported by the Strategic Priority Research Program of the Chinese Academy of Sciences (XDB03020104), the Ministry of Science and Technology of China (2012CB821906), and the National Natural Science Foundation of China (40730210).

1 Bubenik A B. Epigenetical, morphological, phyiological, and behavioral aspects of evolution of horns, pronghorns, and antler. In: Bubenik G A, Bubenik A B, eds. Horns, Pronghorns, and Antlers: Evolution, Morphology, Physiology, and Social Significance. New York: Springer-Verlag, 1990. 3-113

2 Schaurte W T. Darstellung eines Elasmotherium in der Felsmalerei von Rouffignac. Nat Mus, 1964, 94: 354-356

3 Antoine P O. Phylogénie et évolution des Elasmotheriina (Mammalia, Rhinocerotidae). Mém Mus Natl Hist Nat, 2002, 188: 1-359

4 Antoine P O, Welcomme J L. A new rhinoceros from the Lower Miocene of the Bugti Hills, Baluchistan, Pakistan: The earliest elasmotheriine. Palaeontology, 2000, 43: 795-816

5 Kurtén B. Pleistocene Mammals of Europe. New Brunswick: Aldine, 2007. 1-317

6 Ringström T. Nashörner der Hipparion Fauna Nord-Chinas. Palaeont Sin, Ser C, 1924, 1: 1-156

7 Beliajeva E I. New materials of Tertiary rhinocerotoids of Kazakhstan (in Russian). Trav Inst Pal Acad Sci SSSR, 1954, 47: 24-54

8 Beliajeva E I. On some rhinoderoses of the family Rhinicerotidae from the Neogene of West Mongolia (in Russian). Sovm SovetMongol Nauch-Issled Geol Eksped Tr, 1971, 3: 78-97

9 Bayshashov B U. A new species of Sinotherium from the Pliocene of Kazakhstan (in Russian). Paleont J, 1986, 20: 83-88

10 Bayshashov B U. Neogene Rhinoceroses of Kazakhstan (in Russian). Almaty: Gleimei, 1993. 1-147

11 Kondrashev P E. Sinotherium (Mammalia, Rhinoceratidae) from the Early Pliocene of Mongolia. Paleont J, 2000, 34: 655-661

12 Chen G F. A new genus of Iranotheriinae of Ningxia (in Chinese). Vert PalAsiat, 1977, 15: 143-147

13 Deng T. A new elasmothere (Perissodactyla, Rhinocerotidae) from the Late Miocene of the Linxia Basin in Gansu, China. Geobios, 2008, 41: 719-728

$14 \mathrm{Li} \mathrm{J} \mathrm{J} \mathrm{et} \mathrm{al.} \mathrm{Uplift} \mathrm{of} \mathrm{Qinghai-Xizang} \mathrm{(Tibet)} \mathrm{Plateau} \mathrm{and} \mathrm{Global}$ Change. Lanzhou: Lanzhou University Press, 1995. 1-207

15 Fang X M, Garzione C, Van der Voo R, et al. Flexural subsidence by $29 \mathrm{Ma}$ on the NE edge of Tibet from the magnetostratigraphy of
Linxia Basin, China. Earth Planet Sci Lett, 2003, 210: 545-560

16 Deng T, Wang X M, Ni X J, et al. Cenozoic stratigraphic sequence of the Linxia Basin in Gansu, China and its evidence from mammal fossils. Vert PalAsiat, 2004, 42: 45-66

17 Qiu Z X, Wang B Y, Deng T, Mammal fossils from Yagou, Linxia Basin, Gansu, and related stratigraphic problems. Vert PalAsiat, 2004, 42: 276-296

18 Flynn L J, Deng T, Wang Y, et al. Observations on the Hipparion red clays of the Loess Plateau. Vert PalAsiat, 2011, 49: 275-284

19 Deng T. Character, age and ecology of the Hezheng Biota from northwestern China. Acta Geol Sin, 2005, 79: 739-750

20 Wang J Y, Fang X M, Zhang W L, et al. Magnetostratigraphy and implications of the Heilinding section, the Linxia Basin, Gansu Province, China. Mar Geol Quatern Geol, 2010, 30: 129-136

21 Deng T. Chinese Neogene mammal biochronology. Vert PalAsiat, 2006, 44: 143-163

22 Ma Y Z, Li J J, Fang X M. Records of the climatic variation and pollen flora from the red beds at 30.6-5.0 Ma in Linxia district (in Chinese). Chin Sci Bull (Chin Ver), 1998, 43: 301-304

23 Guérin C. Les rhinocéros (Mammalia, Perissodactyla) du Miocène terminal au Pléistocène supérieur en Europe occidentale: Comparaison avec les espèces actuelles. Doc Lab Géol Lyon, 1980, 79: 1-1184

24 Deng T. New discovery of Iranotherium morgani (Perissodactyla, Rhinocerotidae) from the Late Miocene of the Linxia Basin in Gansu, China and its sexual dimorphism. J Vert Paleont, 2005, 25: 442-450

25 Deng T. Skull of Parelasmotherium (Perissodactyla, Rhinocerotidae) from the Upper Miocene in the Linxia Basin (Gansu, China). J Vert Paleont, 2007, 27: 467-475

26 Nielsen D. Victoria regia's bequest to modern architecture. In: Brebbia C A, Carpi A, eds. Design and Nature V: Comparing Design in Nature with Science and Engineering. Southampton: WIT Press, 2010. 65-76

27 Chiu C S. A new genus of giant rhinoceros from Oligocene of Dzungaria, Sinkiang. Vert PalAsiat, 1973, 11: 183-191

28 Qiu Z X, Wang B Y. Paracerathere fossils of China. Palaeont Sin, New Ser C, 2007, 29: 1-396

29 Deng T, Qiu Z X. First discovery of Diceros (Perissodactyla, Rhinocerotidae) in China. Vert PalAsiat, 2007, 45: 287-306

30 Borsuk-Bialynicka M. Studies on the Pleistocene rhinoceros Coelodonta antiquitatis (Blumenbach). Palaeont Pol, 1973, 29: 1-94

31 Kahlke R D, Lacombat F. The earliest immigration of woolly rhinoceros (Coelodonta tologoijensis, Rhinocerotidae, Mammalia) into Europe and its adaptive evolution in Palaearctic cold stage mammal faunas. Quat Sci Rev, 2008, 27: 1951-1961

32 Zeuner F E. Die Beziehungen zwischen Schädelform und Lebensweise bei den rezenten und fossilen Nashörnern. Ber Naturf Ges Freiburg, 1934, 34: 21-79

33 Heissig K. Rhinocerotidae (Mammalia) aus der Anchitherium-Fauna Anatoliens. Geol Jb B, 1976, 19: 3-121

34 Forteliu M, Heissig K. The phylogenetic relationships of the Elasmotherini (Rhincerotidae, Mamm.). Mitt Bayer Staatsslg Paläont Hist Geol, 1989, 29: 227-233

35 Deng T. Paleoecological comparison between Late Miocene localities of China and Greece based on Hipparion faunas. Geodiversitas, 2006, 28: 499-516

36 Groves C P. Ceratotherium simum. Mamm Species, 1972, 8: 1-6

37 Liang Z, Deng T. Age structure and habitat of the rhinoceros Chilotherium during the Late Miocene in the Linxia Basin, Gansu, China. Vert PalAsiat, 2005, 43: 219-230

38 Guo Z T, Ruddiman W F, Hao Q Z, et al. Onset of Asian desertification by $22 \mathrm{Myr}$ ago inferred from loess deposits in China. Nature, 2002, 416: 159-163

39 Guo Z T, Peng S Z, Hao Q Z, et al. Late Miocene-Pliocene development of Asian aridification as recorded in an eolian sequence in northern China. Glob Planet Change, 2004, 41: 135-145

Open Access This article is distributed under the terms of the Creative Commons Attribution License which permits any use, distribution, and reproduction in any medium, provided the original author(s) and source are credited. 